第11回日本医学シミュレーション学会シンポジウム 日臨麻会誌 Vol.37 No.1, 116 120, 2017

伝えるカをみがく

\title{
伝わるプレゼンテーションのありかた 「ポイントを絞って文字数を減らせ」
}

森本康裕 $^{*}$

[要旨］プレゼンテーションでは，限られた時間内にできるだけ多くの情報を聴衆の記憶にとどめ ることが重要である.ずばり「ポイントを絞って文字数を減らせ」が本稿の主張である. 一般演題 を想定すると, まず「はじめに」「対象と方法」「結果」「考察」「結語」といった定型的な流れがあ る. まずは形に沿って必要な情報を書き出す. 次に, 内容をよく吟味して重複した表現など内容を 簡潔にしていく．できるだけ短い単語を組み合わせて模式的に表現したい．その上で，図にできる 部分はできるだけ図で表現する. グラフや表も単にデータを入れるだけでなく，より見やすいよう に設定を細かく修正することが重要である. 最後の作り込みで伝わり方が大きく異なってくること を強調しておきたい.

キーワード : プレゼンテーション, パワーポイント, グラフ

序

プレゼンテーションでは，限られた時間内にでき るだけ多くの情報を聴衆の記憶にとどめることが重 要である。そのためには詰め込みではなくポイント を絞ったスライドの構成が重要になる。主役を強調 するためには多くの情報は省略する必要がある。ず ばり「ポイントを絞って文字数を減らせ」が本稿の 主張である. 以下，学会での一般演題の発表を想定 して効果的なプレゼンについて考えてみたい.

\section{I スライドを作る前に}

一般演題での発表は, スライドあるいはポスター が 10 枚程度まで. 発表時間は 6 分程度である.まず, この発表の条件を確認し発表時間に合った分量を考
える必要がある，ただし，最初から発表内容を制限 すると要点のみの面白くない発表になる。最終的な 分量を考えながら，まずきちんと必要な項目を書き 込んでいく，そこから内容を吟味していくことが重 要である。

\section{II タイトル}

タイトルはプレゼンテーションの最も重要な項目 である。よほど有名な演者あるいはトピックな内容 でなければ聴衆はタイトルを見て発表を聴きに来 る。多くの聴衆をつかめるような魅力的な夕イトル を考える。

ここではわれわれの施設の一般演題を例に使って より魅力的なプレゼンを考えてみる.タイトルは「非 観血的血圧測定時のマンシェットによる皮下出血の 
はじめに

非観血的血圧測定はマンシェット装着部位の皮膚の発赤や

皮下出血を生じる。

起

一通常、皮下出血の軽減のため保護材をマンシェット下に 巻いているが、煩雑さ・コスト·測定值への影響が 考えられる。

"YAWARAカフ®(日本光電) は、マンシェットの内袋に ポリウレタンシートを追加し、皮下出血を軽減させる ために開発された。

通常のマンシェットとYAWARAカフ®使用による皮下出血の 頻度を比較検討した。

図1「はじめに」のスライド

検討」であった。まず，**の検討とか**の効果 というタイトルは内容がわかりにくい.ここでは「非 観血的血圧測定時の皮下出血をYAWARA カフは 減少させる」というような, ずばりのタイトルとし たい.

\section{III はじめに}

通常, タイトルの次は「はじめに」のスライドに なる.ここでは研究の背景と目的を簡潔に述べたい. タイトルでつかんだ聴衆を内容まで聴いてみるかと 思わせるのがこのスライドの目的である。通常,

起 : 今回の研究の注目点

承：これまでわかっている事実

転：しかし，今回はこんな点に注目した。そこで このような目的の研究を行う。

という順に記述する。起, 承という流れを, however，こんな点に注目して研究を行ったという流れ が重要である。また, 最後に研究の目的endpoint あるいは仮説hypothesisが明確に書かれているこ とも重要である。

図1は，よくある「はじめに」のスライドである. 通常はこれでよいがさらに文字数を減らすには，文
章をできるだけ文字まで短縮して模式図的に表現す るとよい．聴衆が一度に頭に入るのは，この図の 1 ブロック程度の文字である。文字のままとするので あれば,できるだけ絞り込んで数行以内に収めたい。

\section{IV 対象と方法}

「対象と方法」のスライドで最も重要なのは方法 の部分である。ここを限られた時間で伝えるのは困 難であり, 図やチャートを効果的に使う必要がある。

YAWARAカフという新規の機材がメインであ るが，これについては「はじめに」の部分で皮下出 血を軽減するために開発との夕紹介している。この ような新しい技術, 薬剤については「はじめに」,「方 法」あるいは「考察」のいずれかで説明可能である。 まったく新しい技術については「はじめに」の後で 説明した方がよい場合がある。ここでは「考察」で まとめて説明することとした。

「方法」は図をうまく使ってみた(図2)。このよ うに，プレゼンテーションでの図は必ずしもリアル である必要はない。この程度の図であればPowerPointの基本図形を組み合わせることで作製できる. 


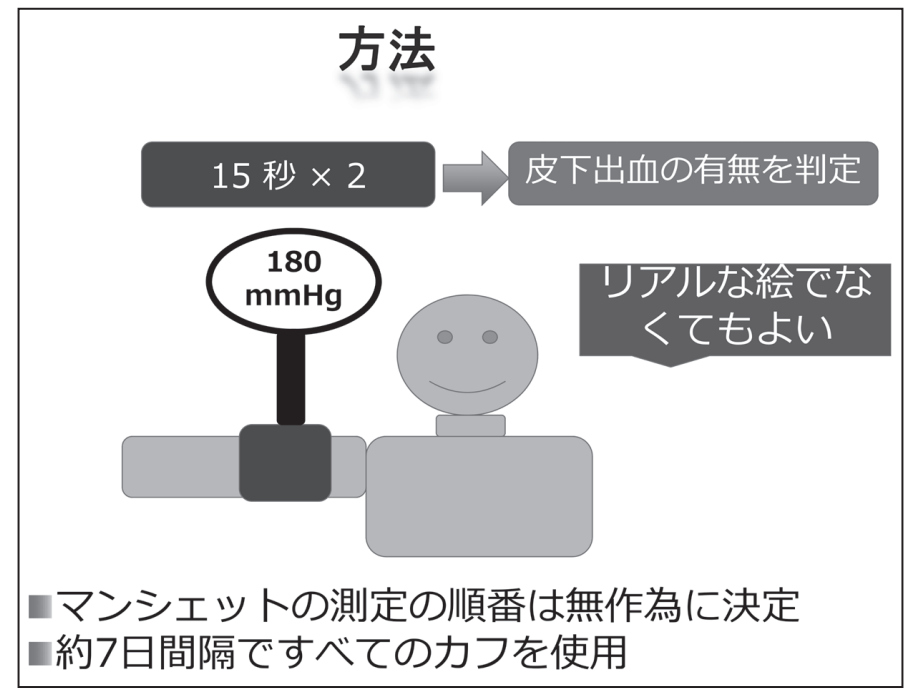

図2「方法」のスライドの例

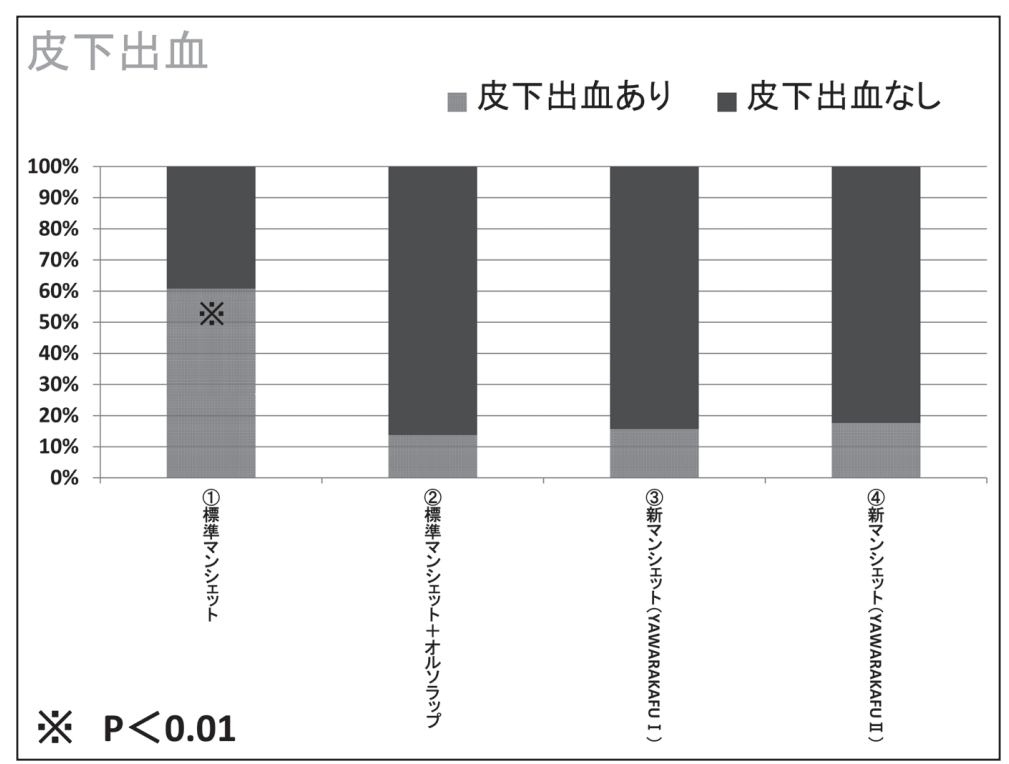

図3「結果」のスライド修正前

\section{$\mathrm{V}$ 結 果}

「結果」は，グラフ>表＞文書でありできるだけ 結果が一目でわかるグラフを描きたい. 図3は PowerPointに単純にデー夕を入れてできたグラフ である、X軸の項目の部分が長いのが気になる。ま た，Y軸の目盛り間隔も一考すべきである。
そこでX軸の項目を横長とし，目盛り間隔も 20 \%ごとにしてみた(図4). PowerPointのグラフや 表はデフォルトのままではなく, 必ずょり見やすい 設定に変更していくのが重要である。配色も今回は 皮下出血は赤色，皮下出血なしは肌色などある程度 意味付けをしてみたい。この他，フォントサイズや 種類, 線の太さなど細かな変更により見栄えのある 


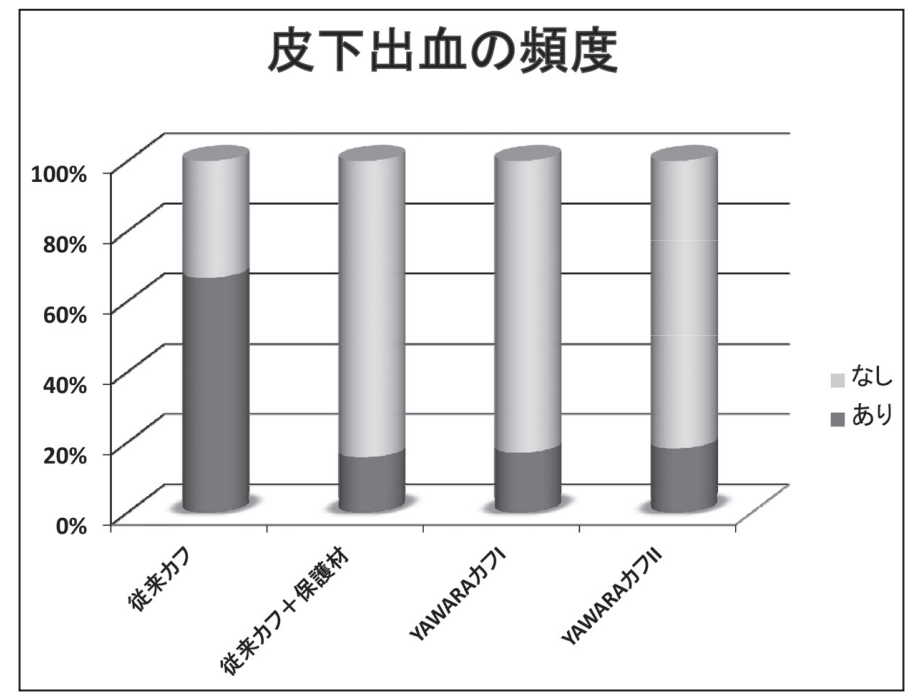

図4「結果」のスライド(修正)

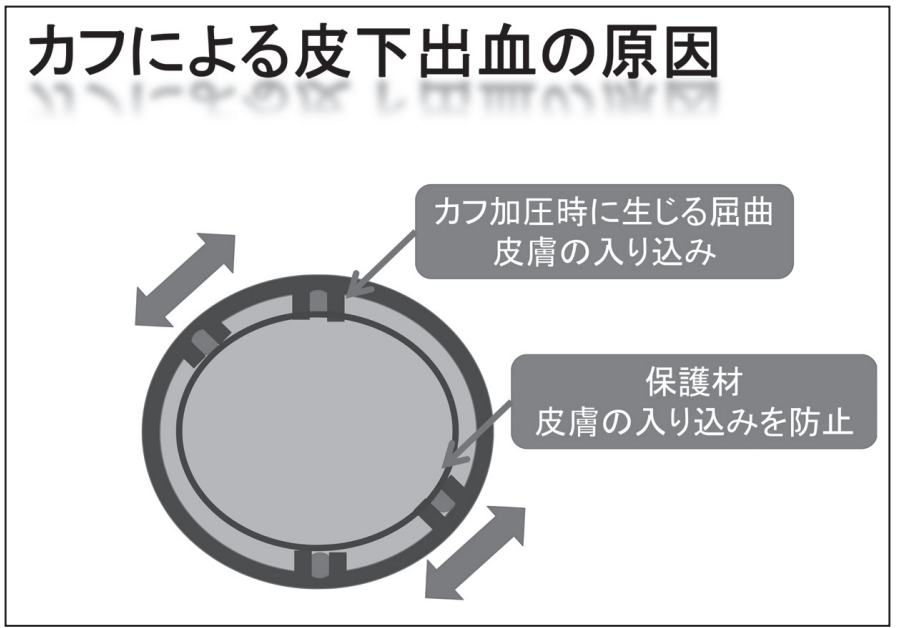

図 5 「考察」のスライド

グラフとなり，本研究の結果が一目で理解できるよ うになる。

\section{$\mathrm{VI}$ 考 察}

「考察」はあくまで結果の解釈にとどめるのが重 要である。しばしば研究の内容を離れて講演になっ ていることがある.今回の研究の結果をまとめて, それがどのように解釈できるのかをいくつかのポイ ントに分けて説明する。ここでも文字だけのスライ
ドにせず図を活用したい.

図 5 は，非観血的血圧測定時になぜ皮下出血が起 こるのかを説明するスライドである。文字だけだと 短い発表時間に聴衆に理解してもらうのはなかなか 難しい。そこで図を使って機序を，次に保護材がな ぜ有効かを説明してみる。一瞬で理解できる図は考 察には必須である。

一般演題の場合，スライドの発表でも凝つたアニ メーションは使いにくい. 必要に応じて複数の図を 
使って説明した方がよいだろう。

\section{VII 結 語}

「結語」は必ずしも読む必要はない。この研究で の結果のポイント, 聴衆に記憶にとどめてもらいた い結論を簡潔に文章にする。

\section{VIII その他}

背景や配色も重要である。ポスターの場合は基本 的に白バックとなるが, 薄い色つきの紙を使っても よいだろう。スライドの発表の場合, 暗い会場とな るので暗めのバックにフォントを白などの明るい色 にした方が目が疲れにくい. PowerPointにはいく つかのテーマが入っているので適宜選択する。ここ もデフォルトのままではなく, フォントの種類やサ イズなどを一部修正して使いたい.

修正はマスタで行うとすべてのスライドに反映さ れる。

前述のとおり, 最初からポイントを絞るのではな く，しっかりと分量を書き込んだスライドを作り， これをゆっくり読んでも制限時間内になるように発
表練習をしながら，ムダな表現を省いていきたい. その過程でスライドの統合や削除も考慮する。最終 的な量の見極め，つまり最後の作り込みが伝わるプ レゼンテーションも最も重要なポイントである.

\section{まとめ}

ここまで一般演題を想定して伝わるプレゼンテー ションのあり方を概説した。一般演題ではある程度, 「はじめに」「対象と方法」「結果」「考察」「結語」 といった定型的な流れがある。まずは形に沿って必 要な情報を書き出す。

次に, 内容をよく吟味して重複した表現など内容 を簡潔にしていく，短時間で聴衆に伝えるには文章 ではなく，できるだけ短い単語を組み合わせて模式 的に表現したい，その上で，図にできる部分はでき るだけ図で表現する。グラフや表も単にデー夕を入 れるだけでなく，より見やすいように設定を細かく 修正することが重要である，最後の作り込みで伝わ り方が大きく異なってくることを強調しておきた い.

\title{
The Keys to an Excellent Presentation
}

\author{
Yasuhiro MORIMOTO \\ Department of Anesthesia, Ube Industries Central Hospital
}

\begin{abstract}
The purpose of presentations is to provide more information within a limited time. To achieve this purpose, narrow the topic and decreasing the number of words is essential. One method is to use short words rather than sentences. The information should be expressed by figures in the methods and discussion sections. Fine adjustments including adjustment of the type and size of fonts is also essential for graphs and tables. The final finishing process is the most important key to a good presentation.
\end{abstract}

Key Words : Presentation, PowerPoint, Graph

The Journal of Japan Society for Clinical Anesthesia Vol.37 No.1, 2017 